\title{
Public Spaces, Citizenship Right and Religion Conflicts in Nigeria
}

\author{
Ola ABEGUNDE ${ }^{1 *}$, Olayide I. OLADEJI ${ }^{1}$, Samuel Babatola AYITI ${ }^{2}$ \\ ${ }^{I}$ Department of Political Science, Faculty of the Social Sciences, Ekiti State University, Ado-Ekiti, Ekiti State, \\ Nigeria \\ ${ }^{2}$ PhD Researcher, Department of Political Science, Faculty of the Social Sciences, Ekiti State University, Ado- \\ Ekiti, Ekiti State, Nigeria
}

*Corresponding Author: Ola ABEGUNDE, Department of Political Science, Faculty of the Social Sciences, Ekiti State University, Ado-Ekiti, Ekiti State, Nigeria

\begin{abstract}
The Nigerian history is laced with obstinate conflicts mostly constructed around differences in political, cultural, ethnic and religious identities. There has been an upsurge in such conflicts since May 29 1999. While much of the conflicts revolve around struggles for the political control, others are hegemonic religion contests that are usually driven by fanaticism and involve claims or denial of the rights to use public spaces for religious purposes. The contestation is wide spread and involves Christianity, Islam and Traditional Religion Worshipers. The paper focuses on religion conflicts involving Muslims and Egungun (Masquerade) Worshipers in Kisi, Irepo Local Government Area of Oyo State, Nigeria. The study utilized descriptive approach to examine the implications of religious fanaticism for citizenship and conflicts in Nigeria. Data were collected from both primary and secondary sources. The study revealed that in Kisi, some 'Muslim fanatics' see and treat public spaces as the exclusive preserve of their religion and thus block the Egungun worshipers from using them for their annual festivals. The forceful resistance usually results to conflicts with severe consequences. The paper recommends continuous inter-faith peace dialogue and intensification of formal and informal civic education on religious tolerance in Nigeria.
\end{abstract}

Keywords: Citizenship, Conflicts, Human Right, Religion Fanaticism.

\section{INTRODUCTION}

Religion, ethnic, boundary and communal conflicts over resources remain a reoccurring destabilizing factor of politics in Nigeria. Since the restoration of democracy in 1999, Nigeria has witnessed domestic instability arising from ethno-religious, religion fanatism, inter and intra communal conflicts, herdsmen/farmers crises and many more with different degree of intensity and attendant casualties. Some of these crises like the Niger Delta militancy and the Boko Haram insurgency in the North East part of the country have challenged the very existence of the Nigerian state with devastating implications for the development and survival of democracy in the most populous country in Africa.

Some of these escalated crises started from elementary level like denial of rights, domination of minority by the majority ethnic groups, exploitation of resources without adequate compensations, denials of access to equal opportunities in terms of educations, jobs and infrastructural facilities. In the specific case of Kisi, a town in Oyo State Nigeria, the domination of Islamic religion over the traditional Egungun worshippers, especially the denial the usage of public spaces (roads, public schools' fields, etc) for the celebration of their religious rites of peaceful gathering and/or procession round the town. This type of discriminatory tendency, especially at the local levels, has been seen as a major and potential source of conflict. ${ }^{1}$ For instance, discrimination on the basis of religion superiority is quiet problematic because it is directly tied to individual or group access to constitutional rights of conscience and association as citizens.

Thus, the discriminatory tendencies over the years have led to buildup of accumulated grievances and tension among the Egungun worshippers in Kisi and the constant violence was just a trigger of long years of anger, frustration and animosity. The crises usually lead to death, disruption of economic activities and destruction of properties worth millions of Naira. Nigeria is prone to conflicts owing to 
lake of rule of law. Since the return to civil rule in 1999, the exclusion and denials of rights and opportunities on the basis of religion have resulted in many cases of violence conflicts. Indeed, the issue of religion and citizenship has been a major dividing factor in Nigeria. Thus this paper grappled with the following questions: What is the nature of religious/citizenship rights in Kisi? What is the nature of inter-faith relations in Kisi? What the remote and immediate causes of religious conflict between some Islamic fanatics and Egungun worshipers in Kisi? What is the position of the constitution on the use of public spaces like roads for religious purposes?

\section{Conceptual Clarifications}

\subsection{Citizenship}

Citizenship is usually defined as full membership in a territorialized/bounded political community. Thus, citizenship could be seen as a transactional reciprocity of rights and duties between a state and her citizens. In other words, citizens are the people who composed a political community and who, in their associational capacity, have established and/or submitted themselves to the authority of a sovereign state/government and who, in return for the protection of their collective wellbeing, reciprocate with certain obligations/duties to the community. ${ }^{2}$ That is, while the state is expected to protect citizens' rights (civil, political, social and cultural rights), citizens in return owe the state certain duties and obligations, which may include tax payment, obedience to the law, voting during elections, defense of the sovereignty/territorial integrity of the state, respect the rights of other citizens, etc. ${ }^{3}$

\subsection{Religion}

Religion has been defined in many ways by different people depending on their orientation and perception. Religion is a narrow sense to refer to a particular group. ${ }^{4}$ It is perceived in a broad sense as the belief systems, moral norms and values held by members of the society. ${ }^{5}$ The foregoing depicts that religion is a difficult concept to define. ${ }^{6}$ However, Peter defines religion as a system of symbols which act to establish powerful, pervasive and long lasting moods and motivations in man by formulating conceptions of a general order of existence and clothing these conceptions with such an aura of factuality that the moods and motivations seen uniquely realistic. ${ }^{7}$ Durkheim defines religion to be a unified system of beliefs and practices relative to sacred things, that is to say things set apart and forbidden beliefs and practices which unite into one single moral community and all those who adhere to them. ${ }^{8}$ The definitions of religion given by both Peter and Durkheim are characterized by the system of beliefs and practices or conceptions relative to a transcendent being, which unite the people into one fervent moral community, a necessary ingredient for religious fanaticism. ${ }^{9}$

\subsection{Fanaticism}

Fanatic is a person who is too enthusiastic about something. ${ }^{10}$ Fanaticism therefore can be referred to as over enthusiasm about a belief. Balogun described religious fanaticism as a violent and unreasoning religious enthusiasm. The tendency for one adherent of religion to misinterprets the doctrine and therefore sees those who are not practicing the same religion as his enemy. ${ }^{11}$ This has led to many religious conflicts in Nigeria.

\subsection{Conflict}

The notion of conflict is negative, but it remains an inevitable part and process of life. Aja described conflict as a frustration based attitude or protest against lack of opportunities for development and against lack of recognition and identity. ${ }^{12}$

\section{Citizenship ANd Religion Conflict: A Theoretical ANAlysis}

The theoretical framework is based in part on the literature on religion and conflict as well as grievances theory developed by Ted Robert Gurr to explain ethnic conflict. ${ }^{13}$ Paul Collier and Anke Hoffler explain the causes of civil wars in African continent. ${ }^{14}$ Gurr's approach combines the relative deprivation approach pioneered in his classic book Why Men Rebel ${ }^{15}$ with the group mobilization approach. ${ }^{16}$ While Gurr controls for many elements, his basic model is very simple and can be described in three steps. First, discrimination against an ethnic minority causes that minority to form grievances. Second, these grievances contribute to the mobilization of the minority for political action. Third, the more mobilized a minority the more likely it is to engage in political action including 
protest and rebellion. In a similar vein, Paul Collier and Anke Hoffler stated that the outbreak of rebellion is as a direct and open manifestation of conflict and possible civil war motivated by injustice. There are three main reasons for it. (i) Inter-group hatred (ii) political exclusion (iii) vengeance ${ }^{17}$

Gurr and Collier and Hoeffler test variations of their model with regard to political, economic and cultural marginalization, discrimination and grievances. ${ }^{18}$ However, they do not test the model using variables measuring religious discrimination and grievance. Since it has been established that religious issues are salient in many ethnic conflicts, and considerable scholarly and anecdotal evidence demonstrates that religion can be a powerful motivating force ${ }^{19} \&^{20}$ Absence of religion from this study is a shortcoming that warrants being addressed. Accordingly, an approach similar to Gurr's and Collier and Hoeffler is used here, especially in testing the relationship between religion discrimination and grievances that usually lead to perennial conflicts on the use of public spaces for religions activities between the muslim and traditional Egungun worshipers at Kisi in Oyo State Nigeria due to religious intolerance.

Two aspects of the literature on religion and conflict justify the extension of Gurr's theoretical framework to religion. The first is that religious frameworks or belief systems are an essential element in the psyche of their adherents. Such belief systems provide a religion's adherents with a framework with which to understand the world around them and allow them to function in it. Accordingly, if a religious framework is challenged in any way, for example by religious discrimination, this challenge constitutes a challenge to the inner souls of that religion's adherents. It is not hard to argue that such a challenge is very likely to cause grievance formation and provoke a defensive reaction among these adherents and that this defensive reaction is likely to be conflictive in nature. ${ }^{21}$

Richard Wentz presents this argument eloquently when he argues that beliefs and values concerning the meaning of life and ultimate order are by definition political. Wentz describes such beliefs as the walls of religion which are psychological walls that people build around themselves and their religious communities in order to deal with reality. ${ }^{22}$ As feudal lords were prepared to defend the walls of their castles and fortresses, some people will do anything to defend the walls of their frameworks. For this reason, violence is frequently justified when religious frameworks are threatened. ${ }^{23}$ Anything is better than the loss of the identities and social solidarity that religious frameworks can provide. The above arguments are sufficient to make the point that challenges to religious framework are likely to provoke a conflictive response from the adherents of those frameworks. This is true irrespective of whether the group challenged occupies a dominant or subordinate role in such society as in the case of dominant Muslim and traditional Egungun worshipers in Kisi.

The fact of the case is that any religion that preaches domination or that infringes on the rights of another group's religious framework as against the provision of the constitution which is the ground norms will definitely force the second group to rise in defense of their own beliefs which is a potential cause of conflict. The deliberate suppression and marginalization of the traditional Egungun worshipers by the Muslim dominated community at Kisi (exclusion and injustice) provided a fertile ground for perennial conflicts between the two groups in which the minority always stands to defend their religion for fear of extermination since exclusion and injustice pervades in total disregard to the provisions of the 1999 constitution. The Egungun worshipers who have been severally denied spaces to practice their religious rites usually ventilate their anger on the Muslim community that leads to occasional violent conflicts in the community.

\section{OVERVIEW OF RELIGION CONFLICTS IN NIGERIA}

Since Nigeria returned to democratic rule in 1999, different religious conflicts have occurred in different states. The first was the institutionalization of sharia as a main body of civil and criminal law in 9 Muslim - majority states of Sokoto, Kano, Kebbi, Zamfara, Bauchi, Katsina, Jigawa, Yobe, Borno and in some parts of 3 Muslim-plurality states of Kaduna, Niger and Gombe when the then Zamfara State Governor Ahmed Yerima began to push for the establishment of sharia at the state level of government. ${ }^{24}$

Violent religious clashes broke out in the city of Kaduna in Northern Nigeria on February, 21, 2000. Kaduna is the second largest city in the North. The clashes followed a march by tens of thousands of 
Christians to protest the proposal to introduce sharia law as the criminal code throughout Kaduna State. Several churches and mosques were burnt and over 400 people were killed while attempting to flee the violence arena. ${ }^{25}$ Also in 2001, there were riots between christian and muslim over the appointment of a muslim politician, Alhaji Muktar Mohammed, as local coordinator of federal government programme to fight poverty. ${ }^{26}$ Another of such riot killed over 100 people in October same year in Kano State. ${ }^{27}$ In 2002, a Nigerian journalist, Isioma Daniel wrote an article that led to the demonstration and violence that caused the death of over 200 in Kaduna. ${ }^{28}$ Fatwa was placed on her life. ${ }^{29}$ The 2002 Miss World contest was moved from Abuja to London as a result of religion tension and such will further aggravate the already fragile peace. The reaction to the Mohammed cartoons brought about a series of violent protests in Nigeria. Clashes between rioters and police claimed several lives, with estimates more than 100 death. ${ }^{30}$ This led to reprisal attacks in the south particularly in Onisha where more than 100 lives were equally lost. ${ }^{31}$

The Boko Haram insurgency that have been ravaging the north east since 2009 was at first a major onslaught against the Christians by the Islamic fundamentalist that has led to burning and bombing of many churches, death of several people and displacement of over 2.1 million in Nigeria as at $2015 .^{32}$

\subsection{The Nigerian Constitution and Religion Rights}

The Nigerian constitution which remains the grandnorm and the embodiment of rules that guides all human activities and interactions grant every citizens of the country the right to practice any religion of his/her choice without any form of discriminations. The fundamental right (human rights) to freedom of thought, conscience and religion is enshrined in section 38 of the constitution of the Federal Republic of Nigeria 1999.

\section{Section 38: Right to freedom of thought, conscience and religion}

- Every person shall be entitled to freedom of thought, conscience and religion, including freedom to change his religion or belief, and freedom (either alone or in community with others, and in public or in private) to manifest and propagate his religion or belief in worship, teaching, practice and observance.

- No person attending any place of education shall be required to receive religious instruction or to take part in or attend any religious ceremony or observance if such instruction, ceremony or observance relates to a religion other than his own, or a religion not approved by his parent or guardian.

- No religious community or denomination shall be prevented from providing religious instruction for pupils of that community or denomination in any place of education maintained wholly by that community or denomination.

- Nothing in this section shall entitle any person to form, take part in the activity or be a member of a secret society.

Section 42 of Chapter iv of the constitution provides for the rights to freedom from discriminations. It also states that, a citizen of Nigeria of a particular community, ethnic group, place of origin, sex religion or political opinion shall not (a) be subjected to disabilities or restriction to which citizen of Nigeria of other communities, ethnic groups, places of origin, sex, religions, political opinions are not made subject or (b) be accorded any privilege or advantage that is not accorded to citizen of Nigeria of other communities, ethnic groups, places of origin, of chapter iv of the constitution provides for the rights to freedom from discriminations. It also states that, a citizen of Nigeria of a particular community, ethnic group, and place of origin, sex religion or political opinion. ${ }^{33}$

The above two sections of the 1999 constitution are clear guarantee of the rights of the citizens of the Federal Republic of Nigeria to practice their religion without any form of restrictions, suppression or discriminations. In consonance with these provisions, all citizens irrespective of his/her ethnic background, sex, colour, or political affiliation has the right to practice their religious beliefs without infringing on the rights of others.

\subsection{Public Spaces and Religion Conflict in Nigeria}

The issue of conflict among religious groups especially in a secular state like Nigeria is not farfetched. While christian/muslim have history of many clashes such as the christian and muslim clashes at 
Kanfanchan in southern Kaduna and the major Islamic uprising led by Maitatsine both in the 1980s. The German Evangelist Reinhard Bonke attempted crusade in Kano that caused a religious riot leading to the deaths of about a dozen people. ${ }^{34}$ Religious conflict between muslims and christians has erupted several times since 2000 for various reasons, often causing riots with several thousands of victims on both sides. ${ }^{35}$ However, direct conflicts between christians/traditionalists or muslim/ traditionalists were rare in the past. But now, tension did flare between the two groups as each group radicalized. Few of such suffice recently in Ekiti and Oyo State Nigeria where the Egungun (masquerades) adherents and muslim lock horns resulting to serious conflict leading to many injuries and destruction of properties. At Ikun Ekiti on $30^{\text {th }}$ May, 2017, there was a violent clash between the Ikao masquerades (Egungun) and the Muslim group over who has the right to use an area where Ansar-ud-Deen Central Mosque and Ajagunmole shrine were located 20 meters away from each other. According to the narratives, the Egungun festival is celebrated once in three years and it demands absolute silence and solemness, however, the Ramadan fast of the muslim group fall on the same time and they usually gather for prayers every day. The Egungun required silence and the muslim required making noise during their call to prayer. In an attempt to maintain peace, the traditional ruler of the town Oba Olatunde Olusola submits that he had written letter to the muslim to use another mosque that day which is only one day in three years but they will not budge. According to him:

There has always been a crisis between them (Egungun \& Muslim) because the shrine is very close to the Mosque; that is why we took the step of informing the various bodies before hand, to avoid trouble. Because they (Eguungun) have to go to their shrine there's always trouble that is why I wrote a letter to them to ask them to do their thing which takes less than one hour". ${ }^{36}$

Unfortunately the Muslims would not yield to the advice in the letter of the monarch to use the alternative mosque for their activities for the one day in three years. The vanguard newspaper gathered that it was the Muslims' loud call for prayer that irked the masqueraders, and prompted a violent reaction from them. They descended on the muslims with cudgels, stones and metals resulting in varying degrees of injuries among the muslims just as the mosque was vandalized. Windscreens of two vehicles parked at the mosque were also smashed just as the panes of the mosque's windows. ${ }^{37}$ Again, in Ado-Ekiti, the state capital, sometimes in July, 2017, similar thing occurred when Egungun allegedly caned an Islamic leader. The traditional ruler had to use his power to ban some Egungun worshipers by cutting short the period of their festival to curtail the conflict that arose between them. Also, some Christians lso alleged that the Egungun worshipers enter their churches to beat up their adherents.

\subsection{The Egungun Worshipers and Muslim Conflict in Kisi}

Kisi is the headquarters of Irepo Local Government Area (ILGA) and it is located geographically at the northern part of Oyo State in the southwestern Nigeria. Kisi is believed to have been established prior to colonialism in Nigeria around the $13^{\text {th }}$ century by groups of Baruba, Fulani, and Yoruba hunters and gatherers. ${ }^{38}{ }^{39}$ The town derived its name from the name of one of its founding fathers, Kilisi Yerumo, a Baruba Prince from Nikki in present day Republic of Benin. ${ }^{40}$ Thus, from the word Kilisi, two letters (i.e. letter ' 1 ' and ' $\mathrm{i}$ ') are omitted to form Kisi. ${ }^{41}$ The town is predominantly agrarian with most of its people involve in subsistence farming. The major farm produce are - yam, cassava, beans, guinea-corn, and maize. However, yam is the most prestigious farm produce and Kisi prides itself as the 'Food Basket of Oyo State'.

Apart from farming, religions play prominent roles in the social-political life of the town right from its inception. Just like everywhere in Nigeria, the predominant religions in Kisi are traditional, christianity and islamic religions. Given the proximity of Kisi to Oyo-Ile, the Old Oyo Empire, it was possible for the traditional religion to penetrate the town first. Basically, the traditional religion is dominated by the animistic practice, inanimate or natural phenomenon is taken as objects of worship such as Egungun, Ogun, Iroko, Sango, etc. ${ }^{42}$ However, Sango and Egungun were taken as the two prominent objects of worship. It is strongly believed among the animists that Supreme God (Olodumare) is too great to be approached directly by mere mortals. Therefore, there must be intercession through heroes, heroines and divinities, which would serve as intermediary between them and Olodumare. ${ }^{43}$ 
Also, it was recorded that Christianity got to the town around 1910 through one Joseph Ladipo and within three years of the introduction of Christianity in the town, its adherents constructed a place of worship named First Baptist Church, Kisi. ${ }^{44}$ The third religion, Islam, made inroad into the town around 1868 through the family of Oloyoyo, who was originally from Oyo-Ile and played key roles in the advent and spread of Islam in the town. ${ }^{45}$ Worthy of note is that Islam is the dominant religion in the town and its adherents constitute about $70 \%$ of the population.

As noted before, religion plays a prominent role in the socio-political life of Kisi to the extent that 'you may not be able to hold any political post or traditional stool without playing the religious card' ${ }^{46}$ This makes religious identity and practice worth fighting for in the town. Indeed, Kisi is a microcosm of Nigeria in that the town is geopolitically split into Oke vs. Isale (North vs. South) with the northern part of the town predominantly dominated by Muslims and the southern part almost equally populated by Christians and Muslims. ${ }^{47}$ However, the town was known for interfaith peaceful co-existence until December 25, 1986 during the usual midnight Christmas Eve procession round the town, when the Christian faithful were attacked by some Muslims at the Central Mosque in the heart of the town. ${ }^{48}$

After that attack on the Christians in 1986, there were no records of inter-religious clashes in the town again until 1988, when the Egungun worshipers were attacked by one Alfa Lati and his Omo Ile Keu (Quranic Students). A respondent gave the account of what eventually resulted into bloodletting clashes between the Alfa and the Egungun worshipers as follow:

The crisis started that when one Egungun worshiper (Ojebola) was dancing round the Atipa suburb, where the Egunguns (Masquerades) were to display that day, to pay usual homage to the prominent Alagbaas (Masquerades High Priests) before the commencement of the festival. From nowhere Alfa Lati came and stopped the drummers. He demanded from them the license authorizing them to beat Bata (Traditional Conga Drum) in the town. Ojebola told him that he had never heard it before that someone needed a license to beat Bata. Before we knew what was happening, a fight had started. It was in the milieu of the fracas that Siaba (a big Masquerade) appeared in the scene and the last we heard was gunshots - Alfa Lati was shut at close range by Siaba ${ }^{49}$.

Most of the people interviewed by the authors admitted that the fracas that followed the shooting of Alfa Lati lasted for several hours where dangerous weapons like cutlass, axe, juju, etc were freely used by both parties and took the intervention of antiriot police deployed from Zonal Headquarters of Police in Ogbomoso before the conflict could be brought under control. Also, the conflict marked the beginning of crisis between Egungun worshipers and Muslims on the one hand and Siaba and Alfa Lati on the other hand. However, as pointed out before, religious crisis in Kisi is not limited to Egungun/Muslim debacle only. To be sure, most respondents pointed out that there was a major religious crisis in the town in 2003, which was mostly referred to as Ijab crisis. The crisis involved all the religious groups in the town and was caused by the use of Ijab by some female Muslim students in public secondary schools against the approved school uniform ${ }^{50}$. As a result of the violation of the uniform rule by the female Muslim students and the purported backing from some Muslim leaders in the town, some Christian and Traditional worshiper students also resulted into going to school in their religious robes. ${ }^{51}$

The crisis got to its peak during the December 25, 2003 Christmas celebration procession round the town by the Christians when they were attacked by some Muslim fanatics on the claim of passing through a Mosque singing ${ }^{52}$. Indeed, signboards with inscription Dake Ilu ati ariwo, bowo fun Ile Olorun (Respect the sanctity of God's temple, stop drumming and noise making) are conspicuously displayed in front of virtually all mosques visited. But, a respondent questioned whether such provision is in the Nigerian constitution; what law empowers those (Muslims) to give such order? She queried. ${ }^{53}$ The December 2003 was another event, which further strained interfaith relationship in the town as some traditional worshipers fight alongside Christians against the Muslims. What makes the crisis complex is that some Muslims openly supported the Christians against those they called fanatics pretending to be Muslims. ${ }^{54}$ In fact, there was intra-faith crisis between the Isalat and Hamadia Muslim sects later on that evening. ${ }^{55}$

However, while no religious crisis occurred in the town for over a decade after the 2003 debacle, a 
major interfaith crisis between the Egungun worshipers and Muslims engulfed the town between May 2-3, 2017.56 It was 'gathered that problem started...when a Muslim cleric identified as Alfa Lati insisted that masqueraders observing the annual Egungun festival should not pass through his (Alfa Lati) street, located at Koso, Mapo area of the town.' 57 However, , in deviance to Alfa Lati's order the masqueraders passed through the street, claiming that Kisi town belongs to every indigene of the town, irrespective of religious affiliation ${ }^{58}$. In the melee that ensued between May 2 and 3, 2017 no fewer than 25 people sustained serious injuries. Unfortunately, the clash came at a time when the traditional ruler of the town, the Iba of Kishi, Oba Moshood Arowoduye, was celebrating his 20th coronation anniversary ${ }^{59}$.

From the foregoing, it could be seen that much of the religious clashes in Kisi revolve around the use of public spaces, especially the major streets. This was due to some Muslim fundamentalists believe that it is Haram (forbidden) for Kafiri (unbelievers) to pass through their mosques for religious activities. Unfortunately, there is no law in Nigeria prohibiting the use of major streets for religious purposes, especially when such religious gathering is duly authorized. For instance, a Christian respondent pointed to a case during the December 2003 crisis between Muslims and Christians, when some Muslim fanatics disrupted an educational programme organized by some Christian youths on the pitch of a primary school (Baptist Primary School). Their claim was that the school belonged to government and must not be used to propagate any religious programme. ${ }^{60} \mathrm{~A}$ respondent put it more bluntly:

the truth of the matter is that some elements are hell bent to Islamize Kisi as if the law of Nigeria does not allow for freedom of religion. In fact, some of them refer to the King as Emir instead of Kabiyesii as is the case in Yoruba land. There claim is that Kisi is Emirate that must be govern by Emir ${ }^{61}$.

Unfortunately, we could not talk directly to the King to either confirm or refute this claim as we understood he was not in town when we visited the place. However, a Chief, who volunteered to talk to us, debunked the claim as unfounded. He stated that:

we are all one big family in Kisi; it is just some vagabonds that are using religion to cause trouble. There is no family here (Kisi) where you do not have the presence of all the three religions. But, let me assure you that the palace in conjunction with the government (state and local government) and the security agencies are working assiduously to make this thing a thing of the past62.

Furthermore, all attempt to speak to Alfa Lati, the man who seems to be in the middle of the whole brouhaha, proved abortive. But, a senior Islamic scholar who talked to us dismissed the crisis as having religious coloration. He stated that 'I cannot deny that we don't have some bandits parading themselves as islamic scholars and using that to cause trouble in the town. But, what I know is that they are not muslims; islam means peace ${ }^{63}$.

\subsection{Security Implications of Egungun/Muslim Conflict for the Larger Society in Nigeria}

Religious intolerance has great impacts which are negative, disintegrative, counterproductive, violent and disastrous on Nigerian society. Few of them shall be discussed in this paper.

- The intolerant spirit of religious adherents has often led to religious totalitarianism which seeks to impose religious conformity and uniformity on the society by force and other questionable means. ${ }^{64}$ The failure of various religious groups to co-habit peacefully in a secular society wills always results to friction as in the examples of many religious conflicts in the country earlier mentioned in the paper.

- The claiming of superiority of one religion to the other that manifest in an attempt to dominate can infringe on the fundamental rights of other citizens. The resistance from the oppressed group can lead to wanton destruction of lives and properties and disruption of public order.

- In a developing country like Nigeria, with a culture characterized by ethnic and religious pluralism, violent religious fundamentalism and fanatism are great obstacles to the achievement of social integration and harmony only in a climate of religious pluralism and social democracy, then will the recognition and promotion of the principles of religious liberty and freedom of worship conduct to social integration and harmony. ${ }^{65}$ These are human values which religious 
extremists seek to sacrifice on the altar of religious violence and intolerance. ${ }^{66}$

- Religious intolerance with its divisive and destructive propensities and consequences is the greatest danger to political stability. This is specially so in Nigeria, a secular polity with a religiously pluralistic setting which can only be sustained and nourished in a healthy atmosphere of religious freedom and scrupulous respect for human rights and the principle of the political secularity of the Nigerian nation and polity. ${ }^{67}$

\section{CONCLUDing REMARKS}

This paper examined contested spaces: Citizenship and Religious conflict in Nigeria's fourth republic. Grievance theory was adopted as theoretical framework in explaining the reasons, for conflict between the Egungun worshipers and Muslim in Nigeria with particular reference to Kisi a community in Oke-Ogun area of Oyo State. The study revealed that intolerance and failure of both religion adherents to respect the constitutionally guarantee fundamental rights of others to practice religion of their choice is always the cause of conflict. Any challenge to a religions framework is likely to provoke a defensive and often conflictive response from the adherents of that religious framework. This is true irrespective of whether the group challenged occupies a dominant or subordinate role in society. To resolve this crisis, there is need for massive public awareness campaign and enlightenment in form of civic education on the need for peaceful co-existence and religious tolerance among communities in Nigeria. The state and local government in collaboration with the Kisi community and leaders to constitute joint reconciliation panel that would ensure amicable resolution of grievances, misunderstanding and fears harbored by the people over the years in order to guarantee long lasting peace among religious groups. Finally, the paper calls for continuous inter-faith peace dialogue on the use of public utilities for religious propagation between all the religious groups to be mediated by the traditional institutions and local government authority within the community.

\section{REFERENCES}

[1] Nwanegbo, J, Odigbo, J and Ochanja N.C (2014); Citizenship, Indigeneship and settlership Crisis in Nigeria: Understanding the Dynamics of Wukari Crisis. Journal of Res. Peace Gend. Dev. 4(1): 8-14.

[2] Oladeji, I. O. (2015), Contested Localities: Indigeneity and Citizenship Dilemma in Nigeria, Journal of Contemporary Politics, Vol. 3(1), pp.147-163.

[3] Oladeji, I.O. (2017), Nationalism and Nationalist Agitations in Africa: the Nigerian Tragedy, PhD Seminar presentation, Department of Political Science, Ekiti State University, Ado-Ekiti, Nigeria.

[4] Bohannan, P. (1969); Social Anthropology, London Holt, Rinchart and Winston.

[5] Bliss, K. (1972); The future of Religion. Pelican Books.

[6] Pratt, J.B (1947); The Religious Consciousness. London: Macmillan.

[7] Peter, V.V (1988); Religion in Bernard (eds) Encyclopedia of Social and Cultural Anthropology.

[8] Durkheim, E. (1915); The Elementary Forms of the Religious Life. Trans.J.W. Swain London and Union.

[9] Oluwole T.A and Fadeyi A.O (2013); Religious Fanaticism and National Security in Nigeria in Journal of Sociological Research Vol. 4, No. 1 Macrothink Institute.

[10] Hornby, A.S (1980); Oxford Advanced Learners Dictionary of Current English. Oxford: Oxford University Press.

[11] Balogun, K.A (1983); Religious Intolerance, Harmony and National Building in Jolayemi E.T (ed.) Leading Issues in General Studies, Humanities and Social Sciences: Ilorin: Department of Religions Studies, University of Ilorin.

[12] Aja, A.A (2009); Basic Concepts of Conflict in Miriam Ikejiani-Clark (ed) Peace Studies and Conflict Resolution in Nigeria: A Reader. Ibadan, Spectrum Books Limited.

[13] Gurr, T.R (1993); Minorities At Risk. Washington, D.C United States Institute of Peace.

[14] Collier, P., and Hoeffler, A. (2000); "Greed and Grievance in Civil War" Policy Research Working Paper Series 2355, The World Bank@https://open.knowledge.worldbank. org/bitstream /handle/10986 /18853/ multi page.pdf? sequence $=1$

[15] Gurr, T.R (1970); Why Men Rebel. Princeton, NJ. Princeton University.

[16] Hannigan, J.A (1991); "Social Movement Theory and the Sociology of Religion: Toward a New Synthesis" Sociological Analysis 52, No 4.

[17] Collier and Hoeffler, (op. cit) 
[18] Gurr, J.R and Moore W.H (1997); Ethnopolitical Rebellion: A Cross-Sectional Analysis of the 1980s with Risk Assessments for the 1990s" American Journal of Political Science Vol. 41 No 4.

[19] Juergensmeyer, M. (1997); "Terror Mandated by God” in Journal of Terrorism and Political Violence 9, No 2.

[20] Fox, J. (2000); "Is Islam More Conflict Prone than other Religions? A Cross-Sectional Study of Ethnoreligious Conflict", in Journal of Nationalism and Ethnic Politics Vol. 6 No 1.

[21] Fox, J. ibid

[22] Wentz, R. (1987); Why People Do Bad Things in the Name of Religion in Macon, G.A: Mercer pp 13 - 70.

[23] Fox, J. (op. cit)

[24] Adamu, J. and Anamesere, I. (2014); "Nigerian Sharia Architect defends Laws" cited in Wikipedia Religious Violence in Nigeria.

[25] Mason and Talbot, (2000), Religious Conflicts in Nigeria. Published by International Committee of fourth International (ICFI) World Socialist Website Feb., 28 Accessed on 11/03/2018

[26] Minchakpu, Obed (2001); "Religious Riots in Nigeria Leave Hundreds Dead" Christian Today, $1{ }^{\text {st } O c t . ~}$ Retrieved Online 9/01/18.

[27] BBC Online (2004); "Kano: Nigeria's Ancient City - State" $20^{\text {th }}$ May

[28] HRW (2003); "The Miss World Riots": Continued Impurity for Killings in Kaduna. Human Right Watch, Vol. 15 , No. 13 (A) $23^{\text {rd }}$ July.

[29] James and Owen (2002); Fatwa was Placed on Nigeria Journalist: UK-educated writer Flees after riots over Miss World. The Guardian, London $27^{\text {th }}$ November. http://isioma.net/sds00503.html. Accessed on $11 / 03 / 18$

[30] Christian Today (2006); Churches Burned in Nigeria Riots, Death Toll Passes $127,27^{\text {th }}$ February.

[31] Olsen, T. (2006); 100 + Dead After Anti-Muslim Riots. Retrieved Online on 9/1/18.

[32] Laccino, L. (2015); Nigeria Boko Haram: 2.1m Displaced Due to Deadly Insurgence in International Business Times $8^{\text {th }}$ September. Retrieved online on 9/01/2018.

[33] FRN (1999); Constitution of Federal Republic of Nigeria.

[34] Falola, T. (2001); Violence in Nigeria: The Crisis of Religious Politics and Secular Ideologies BOYE 6 Publishers, at https://www.amazon.com/dp/15804605 26 at wikipedia.com.

[35] Harnischfeger, J. (2008); Democratization and Islamic Law: The Sharia Conflict in Nigeria. Campus Verlag ISBN 3593382563.

[36] Olatunde, O. (2017); Tension in Ekiti As Muslim Community and Traditional Masquerade Worshipers Clash. In the Vanguard $16^{\text {th }}$ June.

[37] Ojomoyela, R. (2017); Tension in Ekiti As Muslim Community and Traditional Masquerade Worshipers Clash in the Vanguard $16^{\text {th }}$ June.

[38] Olaniyi, M. F. (1982), Iwe Itan Ilu Kisi lati odun 1300-1900 (History of Kisi from 1300-1900 A.D). Kisi: Rashid Press, pp.1-10.

[39] Olaniyi (Ibid).

[40] Olaniyi (Ibid); Oyo Voice (2017), Historical Background of Kisi, https://oyovoice.com/historicalbackground- kishi - accessed on February 27, 2018.

[41] Ahmad and Muhamad (2011), History of Islam and Islamic Education: the Roles of Muslim Scholars and Establishment of Madarasahs in Kisi - Nigeria, in Hamid, A.F.A., Kadir, N.A.A., \& Jalani, H. (eds.), Islam and Education, University of Malaya, Department of Islamic History and Civilization Academy of Islamic Studies.

[42] Olaniyi, M. F. (op cit).

[43] Dopamu, P.A. (1986), Esu: The Invisible Foe of man: A comparative study of Shatan in Christianity, Islam and Yoruba religion. Abeokuta: Shebolatan press.

[44] Olaniyi, M. F. (op cit).

[45] Egbe Odo Musulumi (1998), Iwe Itan Islam ni Ilu Kisi (History of Islam in Kisi), National Council of Muslim Youth Organization (NACOMYO), Kisi branch. Ilorin, Ibrahim Kewulere Press, P.2.

[46] Authors' Interview in Kisi, November 10, 2018.

[47] Authors' Interview in Kisi, November 8, 2018.

[48] Authors' Interview in Kisi, November 10, 2018.

[49] Authors' Interview in Kisi, November 11, 2018.

[50] Authors' Interview in Kisi, November 11, 2018. 
[51] Ibid.

[52] Authors' Interview in Kisi, November 12, 2018.

[53] Ibid.

[54] Authors' Interview in Kisi, November 12, 2018.

[55] Ibid.

[56] Daily Post Newspaper (May 4, 2017), 25 injured as Muslim, Egungun worshipers clash in Oyo community; Inside Oyo (May 28, 2017), How our members were attacked by religious fundamentalists in Kisi, group alleges. The Punch Newspaper (May 5, 2017), 25 injured as masquerade followers, Muslim faithful clash in Oyo.

[57] Daily Post Newspaper (May 4, 2017), 25 injured as Muslim, Egungun worshipers clash in Oyo community; Authors' Interview in Kisi, November 12, 2018.

[58] Daily Post Newspaper (Ibid).

[59] The Punch Newspaper (May 5, 2017), 25 injured as masquerade followers, Muslim faithful clash in Oyo.

[60] Authors' Interview in Kisi, November 11, 2018.

[61] Authors' Interview in Kisi, November 12, 2018.

[62] Authors' Interview in Kisi, November 14, 2018.

[63] Authors' Interview in Kisi, November 14, 2018.

[64] Walker, W. ((1976); A History of the Christian Church. Edinburgh: T \& T. Clark Ltd.

[65] Ushe, M.U (2012); Religious Fanatism and Civil Education in Nigeria: A Paradigm for National Development. In Journal of Research in Education and Society; Vol. 3 No. 1 April pp 142-156.

[66] Trevelyan, G.M. (1960); History of England. London: Longmans.

[67] Burke, J.W. (1961); The Church Across the Centuries. New York: St. Paul Publications.

Citation: Ola ABEGUNDE, et.al. "Public Spaces, Citizenship Right and Religion Conflicts in Nigeria" International Journal of Political Science (IJPS), vol 5, no.2, 2019, pp. 20-29. doi: http://dx.doi.org/ 10.20431/2454-9452.0502004.

Copyright: (0) 2019 Authors. This is an open-access article distributed under the terms of the Creative Commons Attribution License, which permits unrestricted use, distribution, and reproduction in any medium, provided the original author and source are credited. 